\title{
LA LECTURA Y LA ESCRITURA EN GUAMÁN POMA: UNA POLÍTICA DE BUEN GOBIERNO
}

\author{
POR
}

\author{
VICENTA CORTES ALONSO
}

La obra de Felipe Guamán Poma de Ayala, cronista de la historia del Perú de antes (el período indígena) y después (el período español), la justifica el autor al "conversan con el monarca al que va dirigida, diciendo que "Concederá como los sabios que componen los libros y los escriben para el servicio de Dios, aunque lo escriba en fábulas, algunos son buenos para el servicio de Dios y algunos para enmienda de vida o para entretenimiento o bien del cuerpo en el mundon (1).

Aquí aparecen, pensamos, los dos móviles que el descubrimiento, conquista y población de las Indias planteaban a los reyes cristianos: por una parte, el servicio de Dios y, para ello, la evangelización de los nuevos súbditos, y por el otro, el buen gobierno de aquellas tierras. Dicho de manera galana como es el "bien del cuerpo en el mundo», una vez que el alma había sido llevada al conocimiento de Cristo. La Nueva Corónica y buen gobierno, por tanto, quiere ser una exposición de la historia total de la tierra y sus gentes, con las nuevas fuentes que Guamán Poma ha ido recogiendo de manera constante, de la tradición de sus antepasados, como más tarde veremos, y de la realidad de la conquista y asentamiento de los castellanos y de su acción de gobierno por parte de las instituciones. Estas deben procurar el

(1) La más reciente edición de la Nueva Crónica y buen gobierno, Madrid, 1987, 3 vols., con introducción crítica de John V. MURRA, Rolena AdORNo y Jorge L. URIoste, forma parte de la Colección Crónicas de América de Historia 16. La cita que copiamos está en la página 1.001, como lo haremos con las siguientes y la referencia a las láminas en su numeración original (folio original, f. o.). La paginación de los tomos es la siguiente: I. I-LXXVII, 1-372; II. 373-995; III. 9961.384 . 
buen gobierno, el Estado y la Iglesia, para que manifestando los errores, el olvido de las leyes y ordenanzas y los abusos reseñados en ella, se puedan remediar los males «para aliviar la conciencia de su Majestad", comprometida en el buen gobierno de los reinos ultramarinos desde el primer momento de su incorporación a la Corona de Castilla.

Para que tal política de buen gobierno pudiera conseguirse, era imprescindible una comunicación diaria y real de las dos comunidades, las dos repúblicas de españoles y de indios, comunicación que no podía llevarse a buen término sin un conocimiento de las respectivas lenguas: de una parte el conocimiento del castellano por los nuevos súbditos, los indígenas, para hablarla directamente y no por medio de intérpretes o lenguas, de la otra, el aprendizaje de las lenguas nativas generales (nahualt, quéchua, aymará, etc.) para la evangelización y servicio de los indios, y su fijación en el alfabeto latino. Algo se había hecho por el árabe en los textos aljamiados en España, así como la transcripción de los topónimos y onomásticos de los guanches que, como los nativos americanos, no poseían alfabeto alguno, al escribirlos en los documentos peninsulares coetáneos. El método para la evangelización y administración de los pueblos en policía, era el de enseñar a leer y escribir a los nativos como a los españoles, asunto que aparece profusamente ilustrado en la crónica de Guamán Poma. Él, con su propia obra, es un ejemplo vivo de este razonamiento, un testimonio de que el camino para dejar constancia, crónica, de lo pasado como prueba para mejorar el porvenir era, precisamente, aprender a leer y llevarlo a la práctica para informarse $y$, una vez sabido, escribir para conocimiento de los demás. Especialmente del Rey, a quien se dirige la obra, como responsable supremo del buen gobierno que se persigue, para bien de todos, para servicio de Dios y para beneficio del soberano y del reino.

\section{El EMPLEO DE LOS TRES CAMINOS: DIBUJOS, QUÉCHUA Y CASTELLANO}

Lo mismo que sucede en otros documentos americanos, la comunicación de las ideas va a utilizar tres caminos coetáneos que ponen al alcance de todo el mundo los textos que se quiere difundir. Para unos lectores analfabetos, todavía no duchos en escribir y leer por el procedimiento español (lengua y escritura), 
los dibujos van a ir presentando una galería de imágenes cuyos símbolos no van a necesitar explicación para los naturales de la tierra (2), que viven en esa tradición cultural de las pictografías. Cuando ya sean capaces de leer, la explicación de los dibujos con textos en la lengua local, -en el caso del Perú el quéchuada un paso de acercamiento al sistema alfabético, mucho más facil y sencillo que los quipos, pero que, a su vez, no será comprensible aunque se lea para un castellano ignorante de la lengua. Si se pretende que lo escrito llegue a los administradores, clérigos y seglares, de las Indias y de la metrópoli, es imprescindible que el texto se ponga también en castellano, la lengua común a todos los reinos, traída por Castilla. La intención de Guamán Poma era que todo el mundo se enterara, porque, dice, "Y así es muy justo que yo dé mi nombre como cronista y príncipe de este reino, entonces vuestra Majestad le dé título» (pág. 1.070), remarcando que él es consciente de su papel de intermediario, al declarar: "Éste no es español, sino indio como vosotros y su mujer india como vosotras, que no fue señora de Castillan (pág. 878), interesado en que los tres vehículos citados den, juntos, una visión completa de los graves asuntos tratados en la crónica.

Sin manifestarlo conscientemente, Guamán ofrece un cuadro de aculturación pleno, querido, en el que va dejándonos datos de un mismo hecho o pensamiento que tiene, tal vez, una sóla lectura pero tres matices complementarios. La riqueza de su información es apasionante, lo que explica la atención que historiadores, filólogos, antropólogos y otros especialistas le han dedicado. Por nuestra parte, creemos que vale la pena tratemos y tengamos también en cuenta la incidencia que en su obra ocupa la lectura y la escritura en la producción de documentos públicos y privados, fuentes sobre las que trabajamos y que, mayoritariamente, son el producto de esta habilidad administrativa de leer y escribir. Sin los documentos, como vamos a ver, no podía darse un buen gobierno en las provincias andinas organizadas ahora por los castellanos, como lo era el nuevo régimen impuesto al imperante de los Incas, desde los territorios de la actual Colombia

(2) Tema bastante estudiado, cuya bibliografía puede verse en los estudios de las ediciones críticas, señalada por Rolena Adorno, que tiene reciente ejemplo en el estudio de Mercedes López BARALT Icono y conquista: La Crónica de Indias ilustrada como texto cultural, Madrid, 1988. Lo mismo sucede con los documentos, como el llamado "Códice Osuna", que transcribimos y editamos en Pintura del Gobernador, Alcaldes y Regidores de México, "Códice Osuna". Madrid, 1973, del que hemos hecho un comentario en "La imágen del otro: indios, blancos y negros en el México del siglo XVI", Revista de Indias, Madrid 1991, no 192, págs. 259-292. 
a Chile, en tan extensa región andina, fin y meta de una política ordenada para que «la tierra venga a más de la cristiandad y policía y limpieza y así dejarán sus erronias» (pág. 839).

\subsection{Los dibujos}

Los dibujos nos muestran de una manera gráfica, clara y contundente, lo que significaba la novedad de la escritura frente al anterior sistema de fijación de la memoria por medio de los quipos. Este procedimiento, también muy estudiado, aparece como algo privativo de los administradores y oficiales del Inca importantes (secretario, contador mayor y tesorero, administrador de provincias) y de un astrólogo y poeta, es decir, un sabio, con lo que tenemos la comunicación de los documentos administrativos y científicos, que, también vemos, se transmiten por medio de cartas llevadas por los correos (3).

Contemplamos estos "escritos" en situación de ser utilizados por sus productores, en el original, de una mayor o menor dimensión. El tesorero tiene, al pie, un cuadro de equivalencias en pictografía, que puede ser un resúmen del documento principal. El administrador de provincia, por su parte, tiene dos documentos de distinto tamaño, presentando el más pequeño a la contemplación mientras el mayor está en reserva, en segundo plano. El de los depósitos del Inca Topa Yupanqui, el administrador muestra al soberano las cuentas del quipo. Como archivera, nos preguntamos el significado de cada uno de estos testimonios, si los más pequeños serían una parte del mayor o un resumen del estilo del cuadro numérico de la pictografía, un documento decisorio o una carta, como la que lleva el chasqui. Guamán no lo aclara. El documento del sabio es, por su apariencia, semejante en forma y tamaño a los administrativos antes mencionados. Pero para este astrólogo, Guamán si dice que «sólo le faltaba leer y escribirn, lo que supone, pensamos, un estadio de formación deficitario para la permanencia y la difusión del saber. No colegimos si, en caso de que se hicieran copias de estos originales, si habría otras personas capaces de interpretarlos, aún siendo andinos culturalmente (pág. 962). Todos ellos, para su interpretación, necesitaban una clave que era mucho más complicada que las

(3) En las láminas de la Crónica citadas en la lista adjunta se enumeran las que distinguimos, para este punto, las de los folios originales $n^{\circ} 335,358,360,348$ y 883 . 
letras de un alfabeto y, por lo tanto, sólo al alcance de los productores y sus ayudantes.

La memoria "escrita" así, dependía en gran manera de la memoria oral. El descifrar el contenido no se resolvía con conocer la forma. Guamán nos dice que consiguió que le descifrara el informante aymará al preguntarle «Ma, villavai» /pero, dígame/. Que le declara al autor /y muestra los quipus y le declara y le da relaciones de los Ingas... de todo le dio cuenta y razón para que lo escriba y asiente en este dicho libro para que la policía vaya adelante" (4). Aunque en el dibujo no aparezca el tal quipo en manos del indio, sí está en acción de informarle, entre la gran concurrencia de los que rodean al autor elegantemente vestido, a la moda castellana del siglo y con sombrero de alta copa redonda, mientras el aymara lleva su borla de personalidad.

Muy significativo nos parece, por otro lado, que al pintar a los regidores que administran la cosa pública, los andinos en la sociedad impuesta por Castilla, su distintivo sea un libro y un quipo, en las manos izquierda y derecha, además de la vara, y que el texto diga: «Regidores /Tenga libro; quipoc, cuenta: Surcococ/contador/ en este reinom lo que podría interpretarse por el libro de las ordenanzas y las cuentas del cabildo indígena. Esta memoria de los quipos, via oral, la "fue escribiendo y sabiendo con habilidad y gracia que le dió Dios y entendimiento para escribir a Dios y a su Majestad", en que contamos de nuevo con las dos cúspides a que dirige su preocupación para el buen gobierno (pág. 370).

Más adelante, al hablar de las crónicas pasadas, enumera y cita los caciques "testigos de vista que le dan noticias", con sus nombres y jurisdicciones (págs. 1. 161-2). En el caso del correo incaico, el proceso de aculturación en el mensaje es completo, pues aunque está hablando de los indios de medio tributo de la quinta calle, titulado "el que siempre está listo», sobre el quipo hay una carta cerrada a la española que, para que no se confunda con otro objeto cualquiera, tiene su nombre propio: «carta». El quipo, naturalmente, no podía confundirse como mensaje que era para el tiempo que describe y sí el papel (f. o. 202).

Los dibujos, pues, como sucede en otros casos y en otra alta cultura, en Mesoamérica dan una información involuntaria de ambas culturas en que, sin apercibirse el autor, los modos de la autóctona y de la impuesta se mezclan de forma natural, con lo

(4) En la lámina 366 escenifica la toma de datos orales y en el texto lo aclara, pág. 370. 
que el mensaje, hoy, debe ser analizado con una crítica de ambas sociedades. El atuendo del regidor es indígena, salvo la vara y el libro, signos de su posición jerárquica; el quipo está manifestando las ocupaciones de administrador y contador de los tributarios, de las cuentas de su trabajo. Está en la categoría de mando que debía saber leer y escribir, como reseña Guamán Poma. Este valor policultural ha sido destacado por Franklin G. Pease, Rolena Adorno, John. V. Murra y Jorge L. Urioste, en las ediciones críticas más recientes de la Nueva Corónica y buen gobierno (5).

\section{DIBUJOS DE LA NUEVA CORÓNICA REFERENTES A LECTURA Y ESCRITURA}

1. Doctrina. Maestros. f. o. 670, a.

2. Cantor. Cantoral. f. o. 666

3. Secretario del Inca, Consejo. f. o. 358

4. Contador mayor y tesorero. f. o. 360

5. Administrador de provincia. f. 0.348

6. Depósitos del Inca. f. o. 335

7. Pregunta del autor. f. o. 366

8. Astrólogo, poeta. f. o. 883

9. Quinta calle. Mocetón. f. o. 202

10. Papa Dámaso. f. o. 35

11. Audiendia real. Buen gobierno. f. o. 484

12. Corregidor de provincias. f. 0.488

13. Escribano de cabildo español. f. o. 525

14. Padre hace petición. f. o. 588

15. Encomendero, petición contra cacique. f. o. 557

16. Principales, sepan hacer petición, interrogatorio... f. o. 770

17. Alcalde recibiendo queja de india. f. o. 654

18. Principales, memoria de los indios. f. 764

19. Escribano de cabildo andino. f. o. 814, a.

20. Mayordomos del administrador. f. o. 806

21. Administradores. f. 0.808

22. Padre Martín de Ayala, sacerdote de misa, f. o. 17

(5) La estudiada por Franklin G. PEASE, aparecida en Caracas en 1980, en la Colección Ayacucho, tiene dos volúmenes. En ella se actualiza la transcripción del texto, según normas que se especifican (págs. XCI-XCII), mientras en la de 1987, cotejada con el original de Copenhague para "corregir pequeños errores que se produjeron en la edición facsímil de 1936", respeta la grafía del texto catellano y se siguen los criterios lingüísticos actuales de refonologización de las lenguas indígenas (pág. XI-XIII). Hemos actualizado los textos que citamos, pues algunas lecturas tal vez sean opinables, p. e. alquilo suple el final de la palabra, que puede bien considerarse como alquiler, pues la otra forma es bastante más inusual. 
23. Ayala el autor. f. 961

24. Emperador don Carlos envía su carta y perdón. f. 0.417

25. Permuta entre padres. f. o. $\mathbf{5 7 0}$

26. Padre vicario general, «tu escriton. f. 0.627

27. Mineros. Cédula del alquier. f. 0.531

28. Regidores, tengan libro. f. 0.800

Sigla: f. o.: folio original

a.: llustración incluida en este trabajo.

\subsection{Las lenguas: quéchua y castellano}

Sobre esta materia los lingüístas han trabajado lo suyo también. Nosotros, como lectores de viejos documentos, como archiveros, tenemos que decir que Guamán Poma leyó mucho, aprendió bien y enseñó deleitando a sus lectores, entre los que nos encontramos, pues nos encantó su léxico rico y gráfico, con vocablos tan singulares como mercachifle, que el Diccionario de Autoridades, según J. Corominas, da como venezolanismo (6). También, como repite una y otra vez, escuchó mucho y «porque yo no viví en tiempo de los Incas para saber todo, que de estas cordilleras lo supe y lo fui escribiendo..." (pág. 916) así, del discípulo de un cantor averigua el tema de los ayunos de los Incas, "y estaba allí un cantor y me lo dijo su discípulo" (pág. 968) y, observador tenaz, "para dar fe de esto, convenía escribir como sentenciador de ojos a vista como se ha proseguido primero de mi» (pág. 989), historia recogida de fuentes orales en las que repite machaconamente en su dedicatoria final que pasó treinta años trabajando (pág. 1.164).

La importancia de no despreciar la «lengua de indio», no sólo para su crónica sino para la vida cotidiana, la pone de relieve cuando trata de los documentos que pueden presentar los naturales a las autoridades (pág. 876). Lo mismo en la predicación, como hizo el "reverendo fray Domingo que escribió del vocabulario, lengua de los indios, que trabajó tanto sin escrito" (pág. 1.001 ), de manera que tal vehículo de comunicación queda ampliamente manifiesto en la crónica. Los vocabularios que acompañan las ediciones críticas, pues, son de una gran utilidad para todos, porque ayudan a comprender la batalla en que el propio

(6) En el Diccionario crítico etimológico, bajo Merced, t. 3, pág. 350. 
autor se debatía al ocuparse de ambos períodos históricos: el indígena y el español.

En cuanto a las lenguas llegadas al Perú, nos parece que el latín, pese a que la enumera entre las que convenía saber para el buen gobierno en el caso de los indios principales, él no estaba en tal situación, pues la fórmula tan clásica «ab intestatom, la escribe kuentestatew al hablar de la triste muerte del virrey don Francisco de Toledo (págs. 468-9). Lo hace como el más ignorante de los escribanos, que repite de oído. Si no era ducho para el latín, era ladino para el castellano que maneja con suma gracia. Pero, ahí los filólogos tienen su campo para ver hasta qué punto, como dice Adorno, asimiló y manejó las lecturas, y por tanto la lengua, para su propio programa polémico e ideológico (7). De todas maneras, sin que hayamos cotejado las transcripciones hoja por hoja, algunas veces las concordancias de género y número nos resultan vizcaínas, lo que puede ser resultado del proceso de aculturación lingüística, pues las abreviaturas que utiliza ya son muy pocas. Adorno dice que "crea sermones, discursos, sátiras que reflejan de una manera magistral los diferentes modos de hablar de la época", pero, tal vez, marcan los distintos grados de aprendizaje también, según en boca de quien ponga el discurso (8); como es el caso del sermón que transcribe Urioste como ejemplo (9).

\section{LA ENSEÑANZA DE LA LENGUA: ACULTURACIÓN MECÁNICA}

La enseñanza de la lengua, para leerla y escribirla, fue una tarea política emprendida desde el primer momento y que, Guamán Poma, como coteja Adorno en su estudio previo, en más de veinte ocasiones la pone de relieve como necesaria para la policía de los naturales. Por ello, es comprensible que elogiara la creación de las escuelas, "y si pudiere, en pueblo grande y chico haya escuela y cristiandad y policía en todo este reino, aunque no quieran los padres y caciques, corregidores» (10), alabando la labor de los jesuítas en este campo.

(7) Adorno, en su estudio, edición de 1987, [1], págs. XXII-XXIII.

(8) Véase el mismo estudio [1], pág. XX.

(9) Véase Urioste [1], págs. LXX-LXXI.

(10) Idem. pág. XXI. "Estudio Padres de la Compañía de Jesús tengan estudio y estudiantes aparte de los indios pobres que conviene al servicio de Nuestro Señor", pág. 490. 


\subsection{Las escuelas}

Tenemos que poner, en primer lugar, el reconocimiento por parte de ambos grupos, maestros y discípulos, la habilidad y voluntad del indio para aprender, pues inteligencia no les faltaba para ello. Si Pedro de Gante lo manifestaba al Emperador para los mexicanos, Guamán Poma lo repite para los andinos, pues "viéndolo, luego lo aprende si ensañale» y "todo lo dicho lo hacen porque son cristianos y políticos» (11). Vemos, de nuevo, que ese aprendizaje va encaminado a los dos polos ya citados, la evangelización y la vida en sociedad organizada de otra manera a la autóctona: a la administración castellana llevada a las Indias. Es decir, como en los principios de la escritura, en Oriente Medio, no se les enseña para la creación poética, sino que su primer fin y meta va a ser la producción de documentos, antes que las crónicas y poemas. Eso, como en el caso de Guamán, vendrá luego y habiendo sido antes teniente de corregidor, secretario o escribano que refrendaba expedientes bajo la firma del juez o del visitador, tal vez intérprete $y$ aún maestro, como señala Pease al estudiar la crónica, pues uno de los títulos que más repite y aprecia es el de licenciado, tan importante en una sociedad dependiente de la pluma y la toga, como era la hispanoandina (12).

En tal sociedad, gobernada por los «papeles que hablan», frase que llega hasta Juan Luis Vives, tenían que ser enseñados todos los que tomaban alguna parte en el buen gobierno. De esta categoría no escapaban las jerarquías indígenas, altas y bajas. Vale la pena recordar que, en caso de resultados positivos, como los había a menudo, los que cometían abusos tenían que enfrentarse a "grandísimos pleitistas y sean bachilleres y bellacos, ladinejos", como eran los principales ladinos don Pedro y don Juan, rechazados por las autoridades españolas que los maltrataban (13). Así, cataloga de mal sacerdote a aquel que "no gusta que haya escuela ni que sepa leer y escribir, quiere que sean fieles idólatras» (pág. 770).

(11) Puede verse Cortés "La imagen del otro..." [2], págs. 263-271.

(12) PEASE, [5], pág. XII.

(13) Puede verse nuestro trabajo La escritura y lo escrito. Paleografía $y$ Diplomática de España y América en los siglos XVI y XVII, Madrid, 1986, págs. 57. Guamán Poma decía "que los dichos corregidores y padres y encomenderos quieren muy mal a los indios ladinos que saben leer y escribir, y más si saben hacer peticiones, porque no le pida en la residencia todos los agravios y males y daños", pág. 504. 
Por ello, establece Guamán una escala de conocimientos que aconseja para ejercer el poder en la república de los indios: desde el Inca hasta el mandoncillo menor y sus tenientes, así como también sus familias. Se ejercía la potestad con el título, documento escrito por la autoridad española (14).

\subsection{Los medios: modelos, formularios, instrumentos, materiales}

El aprendizaje y la técnica llevaba consigo la utilización de unos modelos, que eran bien distintos de las cuerdecillas anudadas que hemos contemplado en las imágenes de los documentos indigenas: unos elementos se refieren a la clase y formato de los escritos, otros a los materiales con los que había que aprender, los instrumentos y las materias escriptorias. Todos estos elementos van a incidir en la escritura, ya se trate de la actividad administrativa o de la creadora.

Es fácil comprobar que los modelos con los que trabajaba Guamán, buen lector, para componer el contenido del texto, como estudian los especialistas en busca de las fuentes orales y escritas de su relato, son los circulantes en las bibliotecas americanas que tuviera a su alcance. Los libros y los documentos, que en sus escritos aparecen, siguen el diseño, la disposición de uso y el significado que habían llegado de Castilla. Los grabados de las obras llegadas a las oficinas provinciales peruanas de Gramática, de Derecho, de Historia, tenían en sus portadas y relato muchas láminas que, sin duda, utiliza en su propia obra.

Los libros como símbolo de saber, de poder, los vemos en manos de los apóstoles San Pedro (f. o. 561), Santiago y San Bartolomé (f. o. 92,639), de su representante en la tierra, el Papa (f. o. 472) y de su delegado el Arzobispo de los Reyes (f. o. 472). El Virrey es la más alta jerarquía civil del reino andino (f. o. 438), tras el que se sitúan los sacerdotes oficiando o predicando (f. 0 . $17,384,478,525,625$ ) y una abadesa (f. o. 482). En el mismo ámbito religioso hay que situar los cantorales de la escuela y del coro, el primero con notación musical y el segundo con el texto

(14) El Inca tiene que ser buen cristiano y saber: latín, leer, escribir, contar y hacer peticiones (pág. 798). El principal lo mismo y cantar (pág. 798). Los caciques de Guaranga, "estudio, leer, escribir y contar, oficios y artificios" (pág. 802). El mandón mayor "leer, escribir, contar y cantar" (pág. 802). El mandoncillo de indios tributarios leer, escribir y contar (pág. 804). El mandoncillo de 50 indios, lo mismo (pág. 806), lo mismo que el de 100 indios (pág. 808), el mandón (pág. 810, 826), sus tenientes (pág. 820) y sus mujeres (pág. 850). Todos ellos debían tener título del rey, virrey o audiencia (pág. 329). 


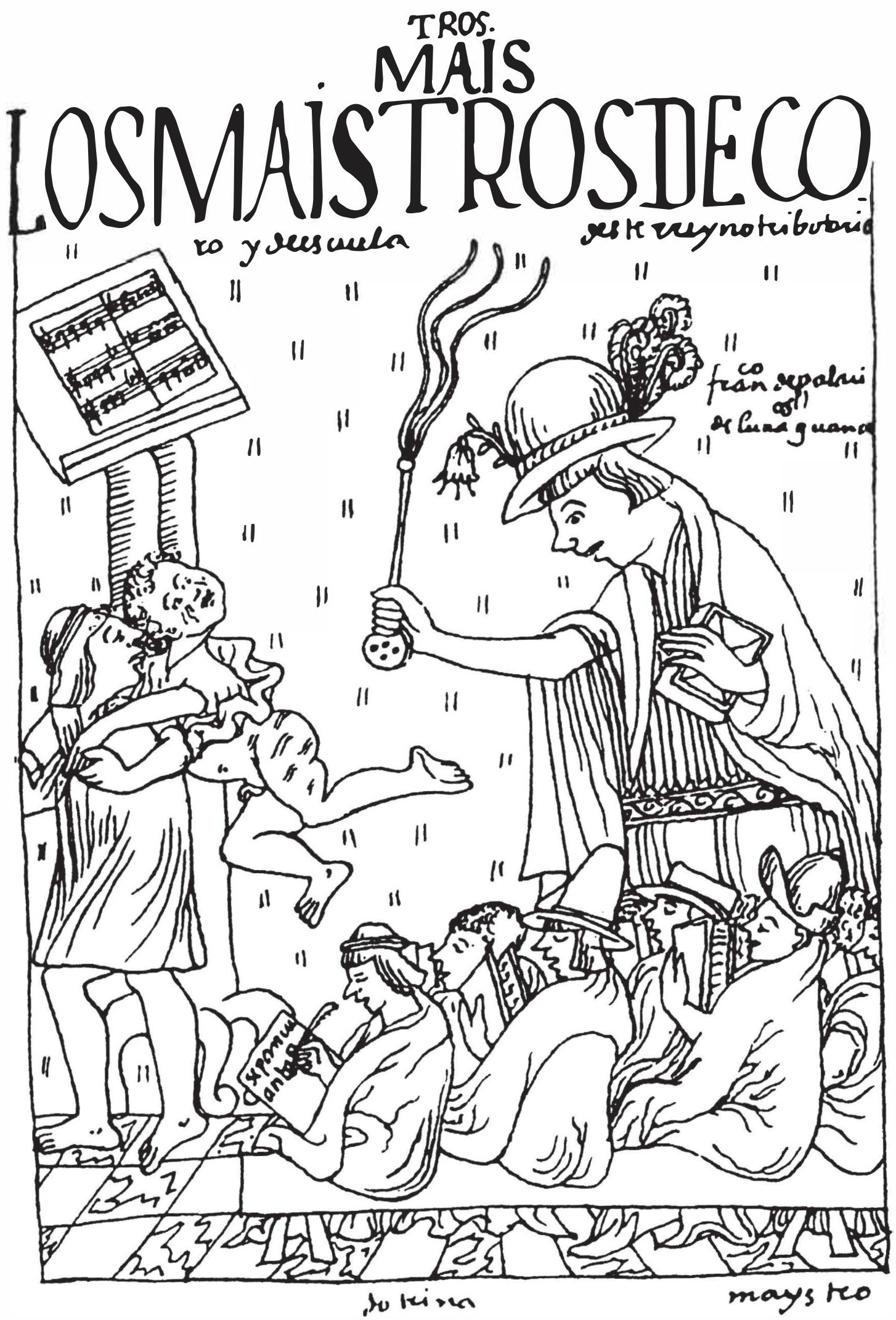

Maestros / Los maestros de coro y de escuela de este reino, tributario, / Francisco de Palacios de Lunaguaná [recuadro: 'sepan cuantos'] / doctrina. 
de la Salve (f. o. 666 y 670). Todos estos, en manos de los introductores del libro, pero lo mismo sucede con los naturales andinos que realizan trabajos en los que la escritura es fundamental. Como escribe Guamán, "El indio principal buen cristiano, lees (pág. 761), lo hace el regidor (f. o. 800), el contador (f. 0.806 y 808) y el escribano para copiar los protocolos del oficio (f. 0 . 873). No podemos, naturalmente, olvidar ahora los libros de creación, junto a los de trabajo y referencia, y aquí se coloca el propio Guamán Poma mostrando su obra al mismo Rey de España (f. o. 961). Merece destacar la seguridad con que el maestro de escuela andino sostiene el libro con su mano izquierda, mientras con la derecha alza el látigo corrector, emblema del principio todavía imperante en algunos lugares, de que "la letra con sangre entra" (f. o. 670).

Una organización política administrando grandes poblaciones, actividades y productos de todo tipo, incluso la actividad bélica, no funciona a plenitud sin los documentos textuales. En los archivos españoles y en los americanos se custodian los miles de escritos producidos por los oficiales reales a partir de la implantación de una burocracia moderna. Gracias a ellos, no hemos perdido la memoria desde 1492 en la mayor parte de los territorios americanos y en las distintas épocas. Por eso, es muy justa la pregunta que se hace J. V. Murra al tratar de la aculturación de Guamán Poma: «chasta qué punto estos retratos dinásticos y sus comentarios reflejan una tradición oral hoy inaccesible?", con motivo de la aseveración del cronista de que "no había matadores ni pleito ni mentira, ni peticiones ni procuradores, ni protector de naturales ni curador interesado ni ladrón sino verdad y buena justicia y ley" (15). Por lo que, sin testimonios sobre soporte perdurable, el mundo andino se presenta como una especia de paraíso terrenal ágrafo. Una vez más, tomamos partido por la administración filipina que no dejaba resquicio al olvido accidental o voluntario. Por eso, pensamos, Guamán insiste contundentemente en el valor de la letra escrita, en párrafo que merece ser copiado:

Que todas las justicias seglares y eclesiásticos de estos reinos reciban las peticiones y memoriales, interrogatorios, avisado o carta que los indios le dieren o presentaren, aunque sea en lengua de indio. Aunque sea un renglón, al pie de ella responda

(15) Vid. Murra, [1], pág. LVII y LXI. 
y con la respuesta se las vuelva para su derecho, justicia, aunque sea indio alcalde. Jamás haga justicia de la palabra, sino que sea de letra, para que le conste al dicho corregidor. Si viniera de palabra, no le oiga y pida escrito. Y así su Majestad verá y proveerá. Y no se las rompa ni se las esconda y no consienta que busque letrado, sino reciban bien hecha, mal hecha las dichas peticiones. De esto reciben muy mucho agravio y así jamás alcanzan justicia ni la tendrá» (pág. 876).

La enseñanza, pues, era un beneficio para los indios ladinos, ladinillos o ladinejos como vemos que los motejan las autoridades que tenian que sufrir sus reclamaciones. Guamán tilda al sacerdote Diego Beltrán de Saravia de gran upapelista», porque con el corregidor, el vicario y otros sacerdotes de los Lucanas y Soras, pues "se juntaron e hicieron cabildo y ordenaron y nombraron notario para hacer información y auto, buscándome la vida, en meneando una paja para vengarse hacia lo criminal y echarme de la provincia y quedar ellos desollando y quitando las hijas a los pobres indios", documentos que sería bueno encontrar, como todos los otros en que intervino, que aclararian la vida y fatigas de Guamán Poma, que sólo conocemos por su pluma (16).

Al hablar de modelos, también hay que referirse a los documentos y a los formularios en que se publicaban. Es significativo que, en la escuela de primeras letras, el modelo que aparece en manos de un infante sea, precisamente, del del comienzo de una carta: "Sepan cuantos...", que es a manera de iniciar los manuales de escribanos, como el principio de su abecedario. Actualmente a los niños, se les enseña a escribir y leer con frases de carácter onomatopéyico, como "mi mamá me ama», que, aparte de la gratificación familiar, no tiene una proyección utilitaria como el "sepan cuantos» (f. o. 670). Más a su favor entonces, tratándose de una clase de doctrina, como se titula la lámina.

A lo largo de su vida, Guamán Poma utilizó la pluma para escribir las 1.189 páginas de su Nueva crónica, pero, sin duda, también la hizo correr para redactar múltiples documentos, por motivos personales o de su trabajo como secretario y amanuense.

(16) Así lo leemos en págs. 1.024-5. Dice Pease "no existe documentación fiable, hasta ahora, que permita una confrontación real de su genealogía andina, ni tampoco, con la exigua documentación de que se dispone, de su biografía personal", [5] pág. XVI. Por eso en la Cronología, págs. 498-99, del tomo 2, las fechas que da son conjeturales. Nos parece sumamente útil la Cronología de España y América Latina (que és más amplia que España y Europa), porque sitúa la creación de Guamán con las obras de sus contemporáneos, crónicas, tratados cientificos, pinturas, arquitectura, etc. 
La letra es bastante correcta, con unas mayúsculas arcaizantes que pueden ser simplificación de los elegantes y a veces complicados abecedarios de los manuales de escritura llevados por los españoles a América (17).

Los instrumentos escriturarios están bien dibujados en las láminas que representan a personajes en actitud de escribir, sean letrados o religiosos, como el papa Dámaso (f. o. 37), el corregidor (f. o. 488), el escribano español (f. o. 525), el padre (f. o. 588), el principal (f. o. 770), el escribano indígena (f. o. 814). Las plumas, el tintero, la salvadera y el estuche de los cortaplumas o navajillas, se colocan sistemáticamente en su lugar preciso sobre la mesa, habitualmente el mismo, acompañados de un rosario y un libro que, bien pueden simbolizar las ordenanzas (ley) y la fidelidad a la palabra escrita (moral), es decir, el buen hacer y el buen testimoniar, representación, a su vez, del Estado y de la Iglesia.

Los soportes de la escritura son ahora el papel y la tinta, distintos de las cuerdas, los tejidos y las vasijas de cerámica. Los buques atravesaban el Atlántico con resmas y resmas de papel, esperadas por los administradores y los vecinos. Buen papel era aquel, capaz de resistir toda clase de accidentes, siendo el tiempo no el menor de ellos. Así lo hace resaltar R. Adorno al comentar el manuscrito de la Crónica, a la que supone algunos borradores perdidos, compuesta por 23 a 25 cuadernillos, algunos de más de 12 folios, todos de solas dos marcas de agua, lo que le hace comentar que tal cantidad y calidad de papel no se corresponde con los lamentos de pobreza de Guamán Poma repetidos en su obra. En ella encontramos otras referencias al papel, cuando cita los capítulos que escribió contra el padre, las cartas de los caciques o las resmas de papel que serían necesarias para escribir la vida y males del indio don Juan Capcha un borracho notable (18). Las tintas, se podían fabricar con pigmentos y óxidos locales. En Perú no se usaba la corteza de árbol, como en México, para escribir los llamados "códices» de henequén.

Libros y documentos eran receptores de lo escrito a mano, así como pasaban a las prensas americanas de la misma manera que lo hacían en España. Muchos eran los registros, copiadores y

(17) Puede verse La escritura y lo escrilo... [13], págs. 5-11. Ejemplo hermoso de la enseñanza es la lámina miniada de la obra de Antonio de NEBRIJA, Introductiones Latinae, 1486, de la Biblioteca Nacional, Madrid, como muestra del respeto al estudio de lo escrito.

(18) R. Adurno lo explica en su estudio, [1], XLI, y lo manifiestan las citas de Guamán, pág. 835. 


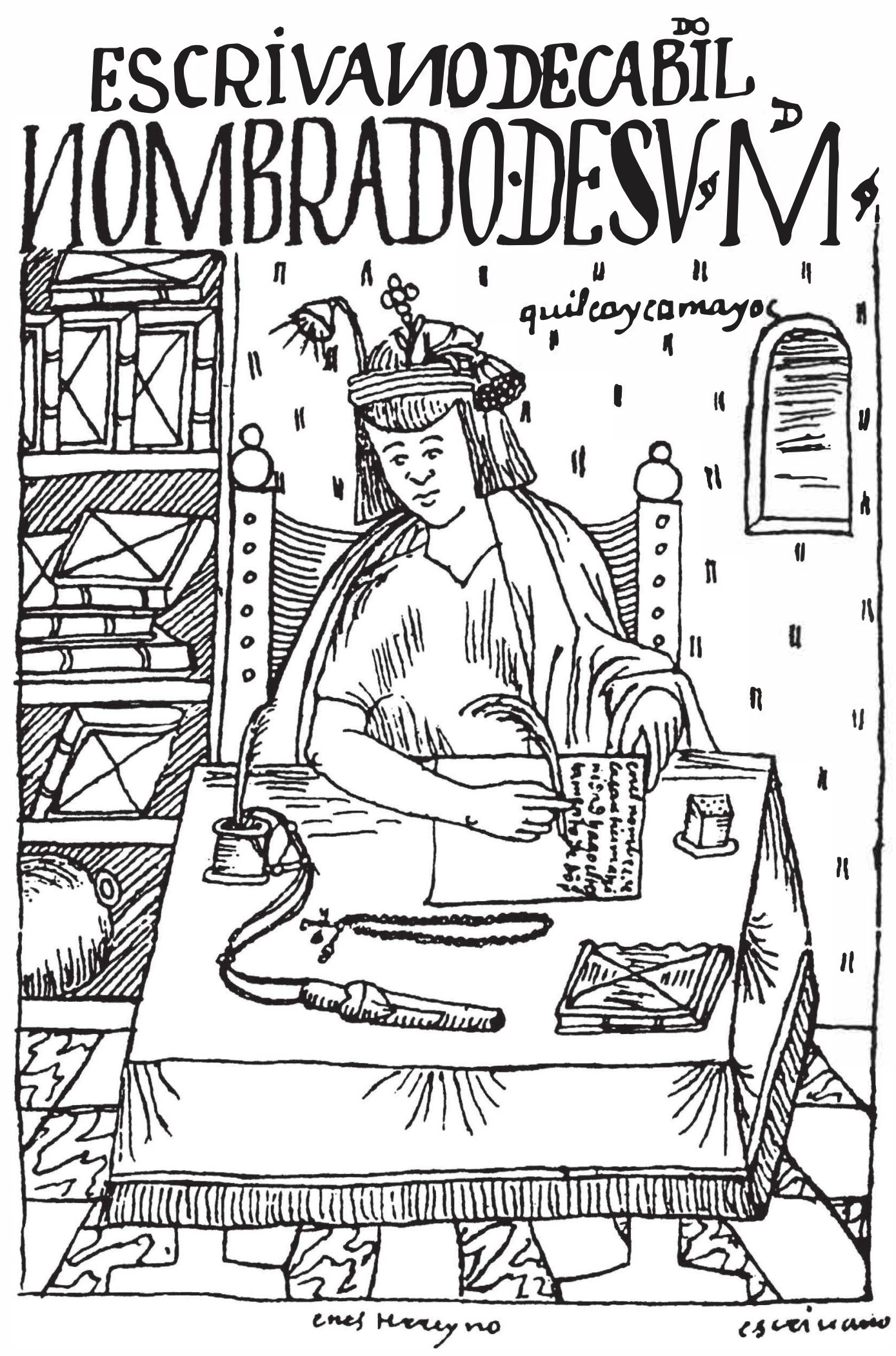

Escribano de Cabildo / nombrado de Su Majestad, Quilcaycamayoc / en este reino [en recuadro: en el nombre de la Santísima Trinidad hago el testamento de don Pedro] 
protocolos que vemos aparecer en los dibujos y el texto, que luego enumeraremos.

\section{El PROCEDIMIENTO ADMINISTRATIVO}

Guamán Poma, como muchos de sus paisanos andinos, comprendió pronto que la lectura y la escritura eran el vehículo por el cual se mantenía la personalidad, se defendía el indivíduo no sólo de los españoles, sino de los propios indios. Que esta habilidad de fijar en el papel, el libro o documento, las ideas, era la espina dorsal de las actuaciones administrativas y creadoras de la sociedad castellana. Y, por ello, si no van acompañadas tales habilidades de la condición de buen cristiano (sin idolatrías, borracheras, etc.), no sólo no hay buen gobierno, sino que va a disminuir el reino en su población y en su riqueza. Se duele, una vez, de que hay indios criados de las autoridades que "aunque sepa lengua y ladino, leer y escribir, pero gran borracho" (pág. 912) no está en el recto camino. En otra ocasión que "siendo bachiller un indio luego se hace por fuerza curaca principal o mandón del dicho ayllo, sin tener título ni tener derecho" (pág. 932). Decía también que las órdenes, sobre todo las que decidían cosas importantes en sus vidas, debían ser dadas por escrito, y así, en el caso de las decisiones de los sacerdotes anotaba que "le llama por tinta y papel y memoria a los indios y a las indias, muchachos y más a las solteras" (pág. 908). Hasta los indios viejos que tuvieran que pedir limosna, lo tenían que hacer por mandamiento (pág. 910). Incluso se necesitaba mandamiento para curar, pues aunque los sanadores indígenas "curan tan bien como doctor o licenciado en medicina» (pág. 884), como a los anteriores, "le deben dar un madamiento para curar y sangrar; lo hacen bien" (pág. 987). Como vemos, las licencias y permisos, eran como los títulos en Castilla. Todo, con arreglo a las ordenanzas. Esta tradición escrita, a diferencia de la oral, no se ha perdido ni tiene que ser retrazada por evidencias secundarias. Los archivos, por lo general, las conservan en abundancia. La oralidad, se puede compensar en sus fallos con los datos textuales de carácter administrativo, tarea esencial de los etonohistoriadores, como sabemos. Quedaba claro en el párrafo que copiamos por extenso, referido a que «jamás haga justicia de la palabra, sino que sea de la letran, incluso en textos de lengua local, como hemos leído. Este es el procedimiento de pesquisas, visitas y residencias, el envío de memoriales y cartas que, también, escritos 
por ofensores y ofendidos, dan cuenta de lo que iba sucediendo $y$, al tiempo, de lo que había quedado en la memoria de los supervivientes... Guamán lo aprovecha todo en su obra, y dice "así en común escribo para el buen ejemplo» (19).

Vemos, pues, que las ocho horas que los maestros debían dedicar a la enseñanza, reguladas por el reloj y la campana, daban buenos resultados en los discípulos más inteligentes y en los estudiantes más constantes (20). La poca o mucha paga que recibieran por ello, en el caso de nuestro cronista, dio su fruto.

El personaje que mantenía la administración produciendo documentos escritos, públicos y privados era, como en la metrópoli, el escribano. La institución se traslada a América desde el primer momento, pues no hay viaje, entrada o asentamiento que no tenga entre sus protagonistas al escribano correspondiente. Lo mismo en los pueblos de indios, como aparece en los dibujos de la Crónica. Cada uno de ellos, con los distintivos personales y culturales que les son propios. El escribano del cabildo español, barbado y cubierto con sombrero, con el equipo de mobiliario e instrumentos escriturarios ya mencionados, recibe la paga de un indio. En otra lámina un sacerdote actúa de notario en un caso de abuso cometido por un corregidor. También un principal actúa como escribano en los pleitos de sus sujetos. Por fin, el escribano del cabildo indígena, «nombrado por su Majestad», está en una oficina semejante a la del español, complementada además por la estantería para los registros, bien rasurado, el cabello motilón y tocado con su banda y borla. El oficio es el mismo, pero los símbolos los distinguen con las características que Guamán especifica sobre la importancia de la apariencia, con una gracia y exactitud ejemplares:

Traiga de manera [el cacique] que diferencie de los indios y aparezca como cacique principal y señor de la tierra. Y si tiene barbas de camarón cocido, que parecerá mestizo, cholo, mala casta, mulato, zamabhigo. $Y$ así ningún indio traiga barbas sino su natural. Y el dicho español sin barbas que parecerá puta vieja, cara de máscara. Al español le honra las barbas y si tuviera cabellos como indio, pareciera salvaje, animal bruto. Su

(19) PEASE lo señala en su estudio, [5], pág. LXV.

(20) Dice que tanto los pueblos como las estancias o minas, grandes y chicos, deben tener "reloj alli de tabla que es de poca costa... A buena cuenta un trabajante en minas o en otras ocupaciones o los oficiales o maestros de escuela de todas las obligaciones y servicios de indios, minga, tienen obligación cada día, ocho horas; aunque sea poca o cara, paga", pág. 926. 
verdadero traje de español vestido y barbudo y motilado es honra del mundo.

El sacerdote clérigo parece muy honrado con su manteo y sotana y bonete y en el camino su sombrero grande de padre, sacerdote, que no monterillas ni ropas de colores... con otro traje, parece farsante sin punta de barbas y corona autoriza. Y si tiene barbas, luego le dicen los indios vira cocha, no le tienen ni le respeta porque muda el hábito ni le teme los españoles ni indios" (pág. 844).

Guamán se muestra partidario de la claridad en los signos que ponen a cada personaje en su étnia, condición y posición pues, como vemos, el hábito nos está diciendo de qué clase es cada monje, cosa sumamente necesaria en una sociedad de variadas gentes y culturas. Cada uno, debe saber a quién tiene delante. Sobre todo, en el ámbito administrativo y de poder. Lo mismo podemos observar en el retrato que hace del escribano como tipo social, que, bien mirado, por sus rasgos no los presenta mejores que lo hacía Quevedo en sus obras. Dice de él:

Escribano entra en los indios como gato cazador. El dicho gato entra y sale dentro de los indios de sus pueblos y casas, muy mansito gatillo misito. De este dicho gato el dueño no siente lo que le hurta; calla callando. De los indios les saca toda su hacienda cuando puede el dicho escribano. Siempre está escribiendo sin causa y está diciendo: "Daca plata y todo reales». Tuerce los autos y lo que manda su Majestad, acompañándose con el dicho procurador. $Y$ se aúnan $y$ son gatos mansitos, bocadulces, que desuellan a los pobres indios de este reino. $\mathrm{Y}$ no hay remedion (pág. 987) (21).

Pese a lo cual, recomendaba que «en cada pueblo ha de haber su escribano nombrado, que éste sea reservado de la tasa y demás obligaciones en todo este reino, que se ha de ejecutarse las ordenanzas de Dios y de su Majestad; aunque sea el más chico pueblo ha de tener su escribano» (pág. 874).

Los documentos, una vez producidos, seguían el camino ascendente de autoridad en autoridad, hasta que la competente resolvía y se terminaba el negocio jurido-administrativo. Eso también lo habían comprendido los súbditos americanos recién alfabetizados, pues reclamaron, pidieron, testaron, escribieron historias y poesías, integrados en una sociedad que no daba un

(21) Para la figura en España, véase La escritura y lo escrito... [13], págs. 2024, y para la Corónica pág. 987. 
paso sin levantar autor de la acción. Los ágrafos, una vez instruidos en la escritura y lo escrito, obraban en consecuencia y los resultados son la Crónica y los miles de metros de actas capitulares, pleitos, protocolos, residencias, etc. que podemos consultar todavía hoy. Todo, por esa política de enseñar al que no sabe, para que pueda participar en el buen gobierno: colaborando o protestando, como Guamán Poma.

El destinatario final, decisorio, de toda la trama era, naturalmente, el Rey. A él se enviaban las cartas, las memorias, las consultas, de los asuntos más diversos. A él, por lo tanto, hubiera querido Guamán Poma entregar su libro, como aparece en la dedicatoria y en la lámina, que idealiza la escena final. El atavío del cronista, semejante al que lleva en la lámina de su recogida de noticias entre los aymara, sigue el modelo de rostro rasurado y pelo cortado, como un buen cacique (22).

Tenemos que hacer mención del hecho de que en la Audiencia, acto de procedimiento oral (aunque los antecedentes sean escritos), no aparece escribano, libro ni documento alguno. Todos los participantes, el presidente, oidores, alcaldes y alguacil mayor están gesticulando de manera gráfica, para manifestar que allí es la palabra la que actúa (f. o. 484). Pero, sabemos que los escribanos estaban en las salas aledañas, con los documentos a punto para la toma de decisiones y la expedición de los papeles del caso. Los indios ladinos, convertidos en pleitistas, daban bastante quehacer a la Audiencia, los cabildos y los notarios.

\section{LOS DOCUMENTOS EN LA CRÓNICA}

Tanto los dibujos como el texto de la Nueva crónica sirven a Guamán Poma para hacer una buena exposición de su conocimiento de los documentos que la buena gobernación exigía, del derecho que en las leyes asistía a los súbditos para poner en marcha los asuntos administrativos - que iban encaminados a mejorar su vida y a tranquilizar con ello la conciencia del Rey, controlando y orientando la actuación de las autoridades delegadas, procurando que fueran sólo las necesarias y muy responsables-, pues se queja, precisamente de lo contrario, por el número y condición de los corregidores, alcaldes, jueces y escribanos. Dice al efecto:

(22) En estas imágenes solo se diferencian los sombreros, el corriente de copa alta y el de corte más cuadrado, y el estampado de las calzas, págs. 337 y 371.

R. l., 1994, $\mathrm{n}^{2} 202$ 
Y así, no teniendo poder ni facultad los dichos vuestros corregidores de las provincias, con color de rescate y trajineador tiene diez tenientes y veinte alcaldes mayores y otros jueces de ollas y de platos tiene ocupado. Como cuesta poco la vara quita un alcalde o se la trae o busca un palo por ahí ello y hace la cruz y trae vara alta de justicia. De manera hay treinta o cuarenta ladrones en cada provincia y jueces, escribanos de cocina y con ellos otros españoles y mestizos. Todos son ladrones y todos comen a costa de los pobres indios. Y cada uno de estos pide treinta indios, indias, mitayos sin pagalle (pág. 1.073).

\subsection{Autoridades españolas}

La máxima jerarquía civil, el soberano, aparece entregando al visitador Pedro de la Gasca una cédula de perdón a Pizarro. Cédulas, cartas, circulando con bastante profusión en manos de los interesados o transportadas por los correos. La persona del Sumo Pontífice, figura escribiendo no bulas o breves, sino la historia de sus antecesores. Los corregidores de provincia, mediante su escribano, comenzaban también a dar cuenta de sus hechos, como en el caso concreto de don Diego de Avendaño. Como Guamán se presenta como teniente general del corregidor en la provincia de los Lucanas y Soras, Andamarca y Circamarca, habla de la confección del censo con conocimiento de causa, así como de que había que llevar un libro de las haciendas de los indios pobres (págs. 868-869).

Los escribanos del cabildo, asentaban en carta de pago las entregas hechas al corregidor, como lo hacía el de don Diego de Mendoza, poniendo las monedas junto a las otras ya entregadas. Los padres ejercían de notarios, escribiendo pedimientos a solicitud de los indios contra los mandatos de los corregidores: «Don Juan Pilcone de Apcara, curaca camachicoc, Digo que el corregidor me pidió indio para trajineadorn. En otra lámina, dos curas se intercambian las permutas de las parroquias que han conseguido, "Tengo hecho ahora esta permuta" y "Permuta de Sus Yamay y de Santiagom. El vicario general en una visita le da un "mandamiento de amparo. Confiad" a un principal anciano. No podía faltar la presencia de los encomenderos en esta producción documental, en que contra el cacique don Juan se presenta al corregidor una petición que, atendida, lo lleva a la horca: "petición contra don Juan", dice el escrito en mano de la autoridad ejecutora. Este trámite, normal en la metrópoli, se repetía en los reinos ultramarinos. Los valedores de los indios en el Perú, mu- 
chas veces, eran los religiosos, como en el caso del vicario general, ya citado, que en la frase quéchua dice "Aqui tiene, hijo, tu mensaje" que se esperaba eficaz y positivo pues decía en castellano: confiad.

\subsection{Documentos de los indigenas}

De la misma forma, una vez aprendido el valor de la letra escrita, aparte de la cantada en la escuela y en la iglesia, también los súbditos americanos sabían que upara que no se las engañe y dé fe el escribano de cabildo, o nombrado, para que valga la fe con testigos y policía que es orden y ley y de nuestra cristiandad y favor de los pobres indios en este reino" (pág. 590). Esta es la razón por la que las autoridades de los naturales, como ya dijimos, debian saber leer y escribir para desempeñar sus cargos, o hacer uso de los escribanos locales para la gestión administrativa y judicial. Las actividades en que los presenta Guamán Poma nos dan idea de los tipos documentales que debían redactar, la mayoría de carácter contable, como sucede con los que muestran los quipos. Vamos a repasarlos por sus cargos a continuación.

La imagen del principal tiene sobre la mesa un libro que bien podía ser las ordenanzas o registro de las cédulas y órdenes recibidas y copiadas. Está en actitud de redactar una carta de pago, cuyo texto manifiesta en lo que lleva escrito: «Del tercio de San Juan pagó 80 pesos Pedro N», que, junto a él cuenta con los dedos la suma (f. o. 770). Los caciques tenían también que llevar «memoria de los indios» que les estaban sujetos, por la que sus mandones debían recoger el tributo (f. o. 764).

Los alcaldes mayores, reconocibles por la vara, debían registrar el asiento del gasto (pág. 850) y firmar las cuentas que se les presentaren (pág. 852), así como tomar la residencia a los anteriores alcaldes, a los párrocos y encomenderos dando información (pág. 857). Los alcaldes ordinarios, debían tener cédula del cacique de lo que se hubiera pagado (pág. 854).

Los regidores, "tenga libro/ quipo" de las cuentas y, para mejor comprenderlas, el libro en una mano y el quipo en la otra, como aparecen en la imágen de los regidores «en este reino" (f. o. 800).

Los administradores de los bienes de la comunidad, las cofradías y el hospital, si lo hubiere, debían llevar el «cargo y libro original y caja», según vemos lo tienen en la mano al abrir el 
depósito de la comunidad con su llave y acercarse a las arcas y cajas del mismo (f. 0.806 y 808). Vale la pena copiar el detalle con que se pedian los datos de cada asiento en el registro del hospital: «asentando la cura y medicina o comida, a quien se le ha dado, su nombre y sobrenombre, hombre o mujer, y de la parcialidad, ayllo, para que se tome en cuentaw (pág. 914). Estos asientos son semejantes a los que hemos leído en los libros de la península, pero queremos destacar que en la filiación se incluye el ayllo, más específico que la vecindad, que sirve para situar a cada indio atendido en su lugar y en su condición familiar. El mayordomo de las cofradias, tenía que pedir carta de pago de las visitas que se le hicieran (pág. 866).

El pregonero, de actividad oral, debía hacer constar su sueldo en la cuenta y razón del administrador (pág. 864). Los correos aparecen llevando las cartas antes y después de la conquista, pues su oficio era de suma importancia tanto para las autoridades como para los vecinos, sobre todo en un territorio tan extenso y de geografía tan accidentada (f. o. 202).

Los indios capitanes de los caciques, encargados de administrar el trabajo y tributo de los indios sujetos, tenían que hacer contratos con ellos por medio del correspondiente documento, la "cédula de alquiler", como lo vemos en el caso de un minero azogado y en trance de morir (f. o. 531).

Donde mayor información encontramos es, por supuesto, cuando Guamán nos habla del escribano que, como memoria del cabildo, tiene que llevar registro de los mandamientos, provisiones y decretos, de manera que recibe los documentos y anota la respuesta que se les da. A su cargo están los libros registro de distinta índole, según las condiciones del pueblo, pues aparte del libro de asiento del tributo (pág. 987), en que por San Juan y Navidad asentará las pagas con la firma del cacique (pág. 1.048), y del libro de las chacras (casi un catastro completo con la calidad de la tierra, cultivos, propietarios, etc.), en aquellos en que haya minas, plazas, tambos, puentes y otros servicios, llevará el suyo. Esencial se presenta, también, el registro del padrón. Cuando actúe como notario, redactará testamentos y otros actos privados, llevando un copiador (protocolo) para sí y dando el original al interesado. Precisamente en la lámina del escribano indígena, está éste redactando un testamento que comienza con la más clásica de las advocaciones: «En el nombre de la Santísima Trinidad hago el testamento de don Pedro" (f. o. 814). Este documento es tan importante, genéricamente, que en el apartado 
de los rezos indígenas en quéchua, Guamán Poma pone una oración que nos parece digna de destacar en dos apartados: "Que Jesucristo me proteja... pueda confesar y hacer testamento a tiempo de morir... guárdame del falso testigo y testimonion (pág. 903), directamente relacionados con la escritura privada y pública.

El padre Martín de Ayala, sacerdote de misa y pariente del autor, es otro ejemplo en la familia del buen resultado de la enseñanza de la lectura y la escritura, para hacer buenos cristianos que sean bien gobernados. Pues aparece el cura mestizo mostrando el libro santo a Felipe Guamán Poma, a su padre y su madre en la ciudad de Guamanga (f. o. 17).

No tenemos muchos datos de los archivos de los cabildos andinos conservados hasta hoy, pero, por lo que nos cuenta el cronista, en líneas generales las series documentales eran las mismas que las de los ayuntamientos castellanos, de los que eran trasunto, como en las otras unidades mayores de la administración indiana, entre ellas la Audiencia.

\section{ACULTURACIÓN RESULTANTE}

Los comentaristas de la Crónica se ocupan bastante de este fenómeno, por demás interesante, de las consecuencias de la lectura y la escritura en el indivíduo Felipe Guamán Poma de Ayala y, mediante su obra, en la sociedad en la que vivía y a la que quería mejorar, el repetido "buen gobierno" propuesto. Podemos tal vez indicar que hay dos planos en los que estudiar el tema, como se hace: en la forma y en el fondo.

\subsection{La forma de la crónica}

Por la lengua, la letra, los dibujos y el texto, aparte los materiales e instrumentos, en la forma la obra de Guamán Poma es el resultado de una enseñanza y un estudio. Más aún, diríamos, de una práctica profesional de lo aprendido desde la escuela, con el «Sepan cuantos».

La lengua, nos atrae por la riqueza de los términos y por lo gráfico de las expresiones. Sólo citaremos la frase de «barbas de camarón cocido" al referirse a los caciques que deban ir sin ellas y al español con pelo largo y sin barbas, que parecerá salvaje y 
animal bruto por lo primero y puta vieja y cara de máscara, por lo segundo. Cuestión aparte son las relaciones gramaticales, las "hablas» que considera R. Adorno. Adjetiva con claridad y sin remilgos, trátese de una comunidad o de la otra. Su nomenclatura documental es correcta, dándonos una lista de tipos que nos permiten calibrar la incidencia de la docencia administrativa en la comunidad andina como positiva. Con el mismo interés con que el Inca pedía cuentas al guardián de sus almacenes, mediante la lectura de los quipos, de la misma manera los visitadores y escribanos tenían que reclamar los testimonios de la acción de gobierno. Ya todos eran «papelistas», lo que en la forma significa un éxito en tan pocos años de mandato español.

La redacción de los "papeles" administrativos se hace con una soltura de fórmulas y una precisión de procedimiento que, por lo que vemos en los archivos que conservan estos testimonios, bien al contrario del cuadro de la época de tradición oral, había muchos pleitos, reclamaciones de abusos, memoriales informativos. La propia Crónica, es uno más. Es, a manera de memorial de agravios con la oferta de la posible solución que, radica, según el autor, en el buen uso de ese saber caligráfico y textual que aparece en todos los capítulos de la obra. En lo que no consiguió seguir los modelos que tenía, fue en presentarla al Rey y, sobre todo, verla impresa y circulando por todas partes, como las de algunos paisanos suyos. Pero las ediciones facsimilares y críticas del ejemplar original guardado en la Biblioteca Real de Copenhague, están heciendo, luego de varios siglos, ese camino. Nos ponen en la mano un testimonio escrito de la aculturación en el Perú, sumamente rico y hermoso.

\subsection{El fondo de la Crónica}

Habiendo leído Guamán Poma los autores españoles a su alcance y escuchado a los naturales que guardaban la memoria de lo que él no había conocido, Guamán, «que se ha leído todas las historias y crónicas del mundo, de los reyes y príncipes, emperadores de mundo, así cristianos como del Gran Turco y del rey chino, emperadores de Roma y de toda la cristiandad y judios y del rey de Guinea (pág. 1.044), nos parece que no está conforme con el gobierno existente, pues, "y así todos los principales y principalas llevemos el camino de los pobres menores, para que nos siga los pobrecitos indios e indias de este reino a sécula, sin fin de Dios» (pág. 878). 
Destaquemos lo de "pobres menores», donde él no se considera situado, para lo que recupera el pasado pre-incaico e incaico y presenta los fallos del actual gobierno, a fin de estar en la historia como personaje con mérito de su pasado y por su presente. Acude a la memoria escrita, a los documentos, para que con el buen manejo administrativo de los mismos, la situación sea beneficiosa para los naturales. Estos, a fin de conseguirlo, aparte de defenderse deberán ser buenos cristianos. Con ambos poderes, la comunicación debe ser por escrito, con el Estado y con la Iglesia, para que no haya testimonio anulado o falso. La escritura, frente a la sociedad oral de la que procedía, es un arma defensiva de los súbditos, andinos y españoles, para evitar el abuso, la pobreza y la muerte de la comunidad (23).

Todo esto, por otro lado, lo podemos leer también en los interrogarorios de los pleitos, visitas y residencias para casi todas las provincias americanas. No es tan frecuente que, como sucede en Guamán Poma y en algún otro "códice", se nos presente el relato en los tres estadios de comunicación: las pinturas, las lenguas nativas y el castellano. Sin que dejemos de anotar lo que significa, para la conservación y fijación de las lenguas indígenas, el aprendizaje de un alfabeto y una lengua en la que van a perpetuarse sus sonidos y significado, en los textos administrativos y, mucho más, en los catecismos y vocabularios de evangelización. De algunas de estas lenguas, lo único perdurable ha sido esta tarea de enseñanza y escritura de maestros y doctrineros, desaparecidos los aborígenes que las hablaron. Esa docencia, que damos por sentado era lo natural como medida de gobierno, de buen gobierno, no fue practicada por todos los europeos que llegaron a otras tierras, americanas o no, ni en otros tiempos. Vale la pena recordarlo ahora, tratando de Guamán Poma, que era, además, Felipe y de Ayala (24).

(23) Para el trámite documental y los archivos que guardan los documentos que nos interesan, puede verse La escritura y lo escrito. [13], págs. 36-55. LóPEzBARALT se ocupa de la importancia de los documentos, que deben conocer y dominar los indios, cuyo "texto legible suele ser muy corto y en muchos casos no aporta nada demasiado importante", dice, pero bien al contrario, esas escasas palabras son tan valiosas como los datos de los dibujos que tanto ensalza, [2], págs. 397-405.

(24) Cuando redactamos nuestro trabajo no se había publicado la obra Documentos sobre politica lingǘslica en Hispanoamérica. 1492-1800. Estudio Preliminar y Edición de Francisco de Solano en la "Colección Tierra Nueva e Cielo Nuevo", Madrid, 1992. 